\title{
IMPACT OF INDUSTRIAL ACTIVITIES ON HEAVY METAL LOADING AND THEIR PHYSICO-CHEMICAL EFFECTS ON WETLANDS OF LAKE VICTORIA BASIN (UGANDA)
}

\author{
Muwanga, A. and Barifaijo, E. \\ Department of Geology, Makerere University, \\ P.O. Box 7062, Kampala, UGANDA
}

\begin{abstract}
The diverse functions of wetlands are being adversely affected by human activities. This paper discusses the impact of these activities on heavy metal loading in different media within the wetlands. Water and sediment/soil samples were taken from areas with active industrial activities and from an area where there is no industrial activity. Sources of water pollution include effluents from a brewery (high $\mathrm{pH}$ ) and areas associated with tanning activities, sewage treatment plant and former copper smelter (high electric conductivity values). Effluents from a battery assembly plant, water treatment plant, pharmaceutical industry and former copper smelter have relatively high $\mathrm{Pb}$ values (up to 1.4 ppm) otherwise most heavy metal concentrations are below maximum acceptable limits for water. This calls for mitigation measures. In sediments, high heavy metal values were associated with battery and metal fabricating industry $(\mathrm{Pb})$, operations involving $\mathrm{Zn}$ scrap $(\mathrm{Cd})$, former $\mathrm{Cu}$ smelter $(\mathrm{Cu}, \mathrm{Pb}, \mathrm{Ni}$ and $\mathrm{Co})$, tannery and pharmaceutical industry $(\mathrm{Cr})$, and soap and cosmetics industry $(\mathrm{Hg})$. Fish have low levels of $\mathrm{Hg}$. However, fish is known to bioaccumulate $\mathrm{Hg}$ through methylation, may cause increase in the $\mathrm{Hg}$ in the food chain. Industries which release effluents with high heavy metal contents should treat them before discharge.
\end{abstract}

Key words: Wetlands, Lake Victoria basin, heavy metals, physico-chemical parameters, toxicity, bioaccumulation.

\section{INTRODUCTION}

Wetlands provide an ecological, social and economic status which contribute to the GNP (Gross National Product) of a nation thus becoming "wealthlands" (Namakambo, 2000; Mafabi et al; 1998, Swallow et al., 2001 and Haskoning - CMS, 2001a \& b). They serve both direct and indirect functions. Direct functions include fishing, fuel wood, wild foods, medicinal plants, agriculture, pasture, transport, recreation (green corridors) etc. The indirect or ecosystem functions include; maintenance of water quality (Kansiime et al., 1995, 2003; Okurut et al., 2000) and flow, water storage, water recharge, flood control, reproduction area for fish, climate control and shore stability. Other functions include cultural, biodiversity of flora and fauna, aesthetic, heritage bequest values and nesting site for birds.
The catchment area of Lake Victoria basin is very densely populated. The functions of the wetlands mentioned above are being adversely affected by the high population and associated increase in human activities including mining and industries. These human activities around Lake Victoria are likely to impact on the water quality and the quality of wetland resources such as fish and food derived from the area.

The industries impacting on the wetlands of the Lake Victoria basin are concentrated in Kampala and Jinja. The operations and effluent management of these industries plus other municipal wastes and urban run-off were found to be negatively impacting on the wetlands in both towns (Mott Macdonald, 2001). The industrial activities include factories of batteries, soap, paint, metal fabrication, plastics, corrugated iron sheets, pharmaceuticals, breweries, tanneries, former copper smelting plant as well 
as municipal waste disposal. Mining activities are minimal and they are not likely to have a significant effect on the wetlands.

For sustainable development of the natural resources of the wetlands in the basin, it is necessary to study the how the industrial activities impact on them. These activities are sources of toxic metals and other chemicals which pollute the wetland ecosystem. This ongoing interdisciplinary study has identified some of the impacted areas and evaluated the heavy metal loads in the different media within the wetlands.

\section{SAMPLING}

The sampling was done during the dry season in the months of December, 2003 to February, 2004 starting in the wetlands around Kampala, Jinja and Busia. The wetlands around Kampala and Jinja are impacted on by industrial activities while those in Busia are considered pristine. The sampled areas are shown in Fig. 1.

The GPS co-ordinates in UTM were recorded for each sampling station followed by measurement of the physical parameters which included acidity $(\mathrm{pH})$, electrical

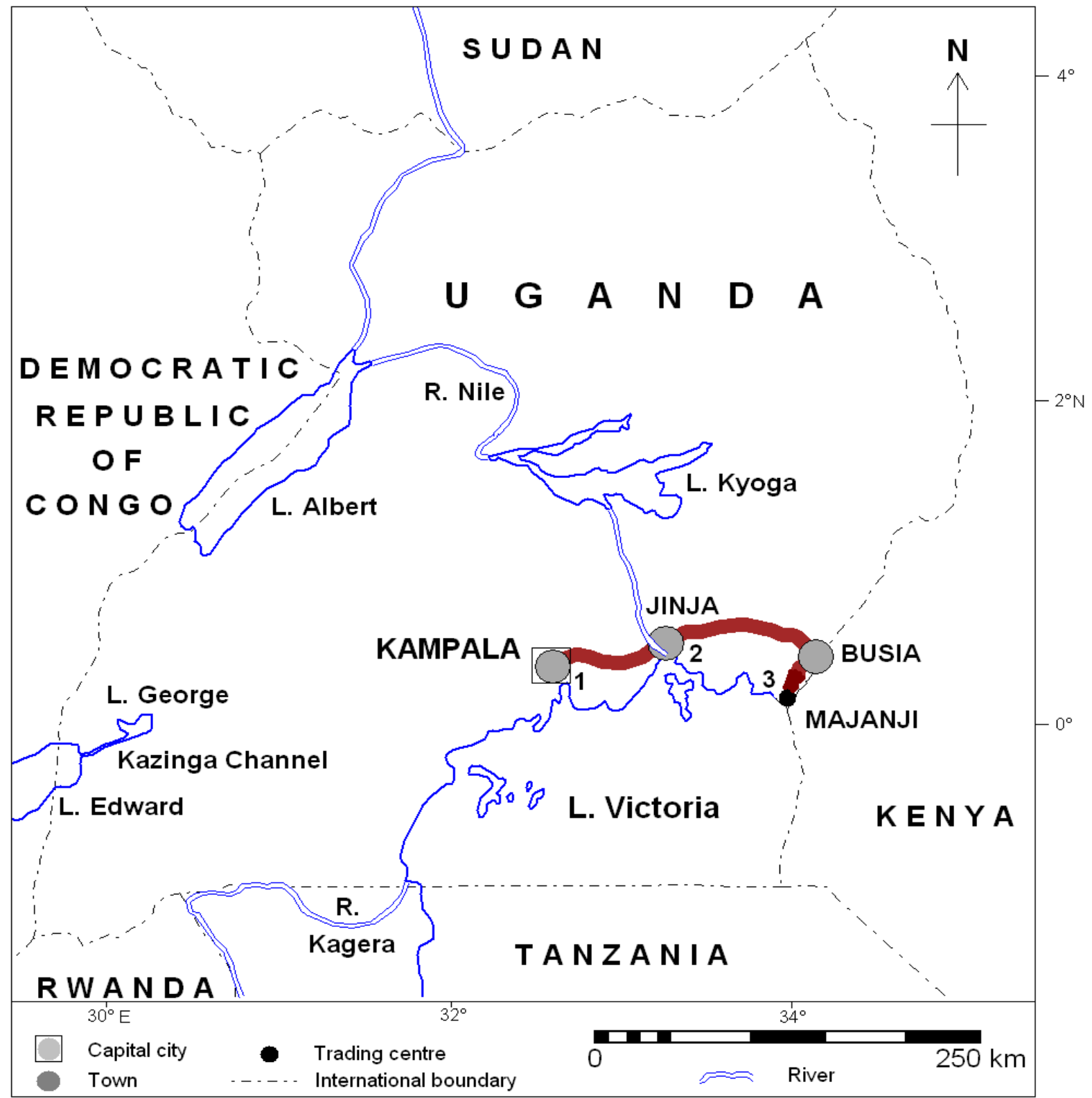

Figure 1: Map of Uganda showing location of study areas (1-3) 
Impact of Industrial Activities on Heavy Metal Loading and their Physico-Chemical Effects on Wetlands of Lake Victoria Basin (Uganda)

conductivity (EC), redox potential (Eh), turbidity (NTU) and oxygen $\left(\mathrm{O}_{2}\right)$ for water.

The sediments and soils sampled using a hand auger were kept in polyethylene bags. Lung fish (Protopterus aethiopicus) which is accustomed to the swampy environment was bought from the local fishermen found within the sampled areas. The sampled materials were preserved in coolers containing ice and later transferred to a deep freezer at the University.

\section{Nakivubo Channel (Kampala)}

The sampling started with the mouth of the channel (NC1) at Bat Valley (Fig. 2) through the bus park and Owino market circuit to Mukwano industries and the remaining industries up to the end of the constructed Nakivubo channel about 50 metres after the railway bridge below Luzira Prison.

The sampling was continued within Lake Victoria to capture the effluents after they had passed through the Murchison Bay wetland.

A sample would be taken both upstream and downstream of any industry in order to ascertain the level of contamination. The streams adjoining the channel both natural for example Kitante and man-made like Kibira plus pipeline bringing in effluent to the channel like the NWSC and Uganda Breweries Ltd. at Port Bell were sampled before they join the channel and a few metres after they had joined.

\section{Kinawataka (Kampala)}

Samples were got from both upstream and downstream the Vubyabirenge, Kinawataka and Fish Packers (Pepsi) streams (Fig.2) and after the confluence of the three streams opposite Kyambogo junction and behind Oxygas plant. Sampling was continued where the effluent water enters the Kinawataka wetland after the Kireka-Mbuya road and Butabika hills up to where it loops and joins Murchison Bay in the Kirombe-Port Bell area.

\section{Napoleon Gulf(Jinja)}

The sampling stations were mostly concentrated on the pipeline of the NWSC (Fig.3) which collects all the municipal and industrial effluents in Jinja town. Samples were also collected from the access transects $1 \& 2$ of the Lake Victoria Environmental Management Programme (LVEMP) within the Kirinya wetland (water from the sewer pipe had gone through the wetland) and in Lake Victoria. There was no lung fish sampled in the Napoleon Gulf as it was unavailable during the time of sampling.

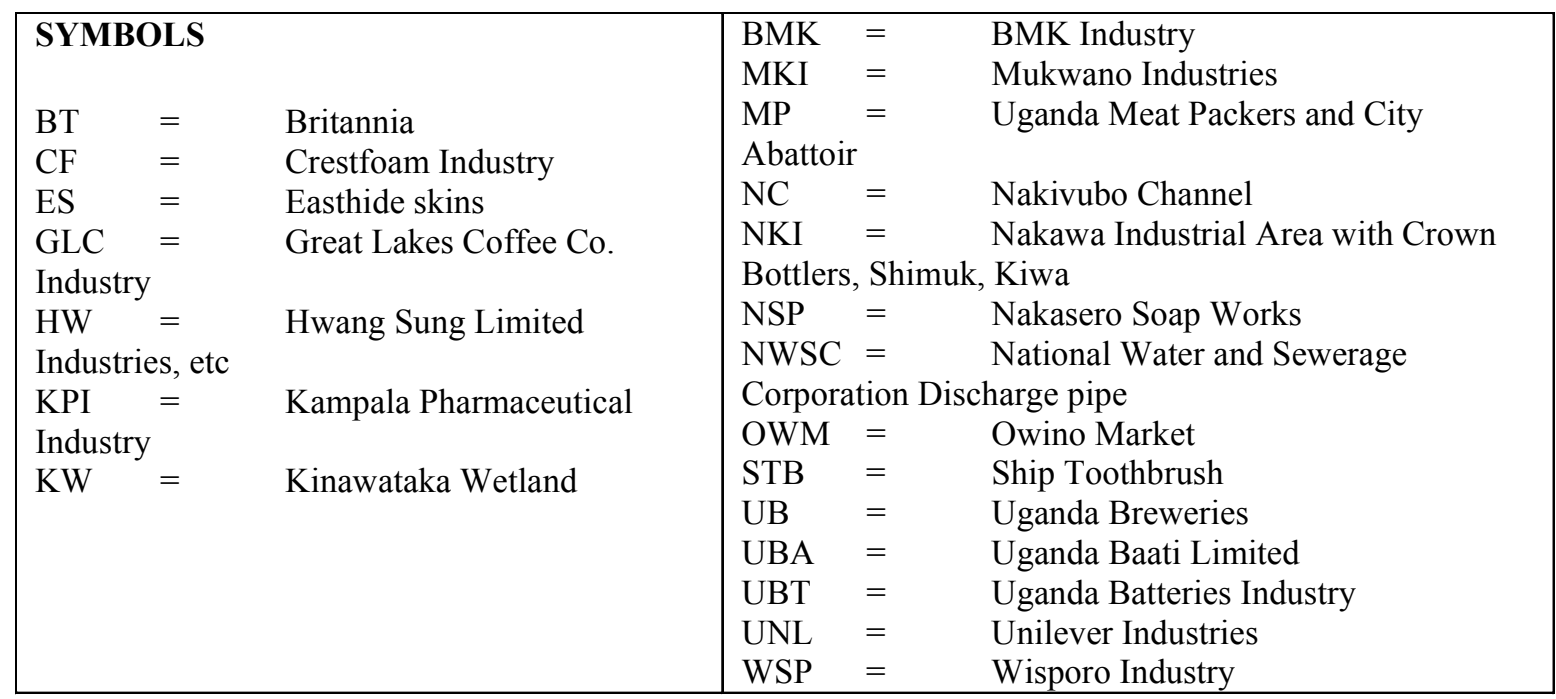




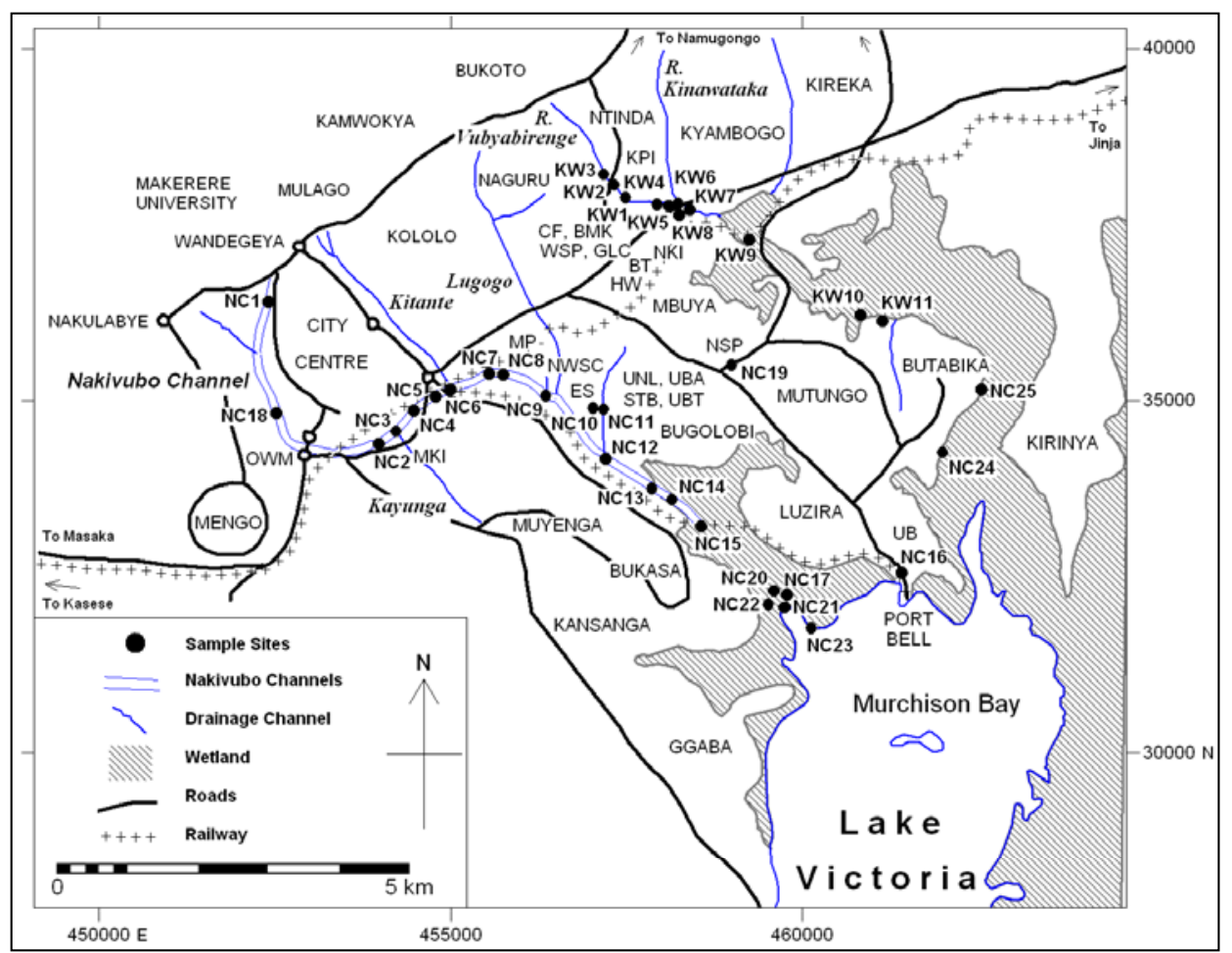

Figure 2: Map showing sample locations along in Kampala (Nakivubo channel and Kinawattaka stream)

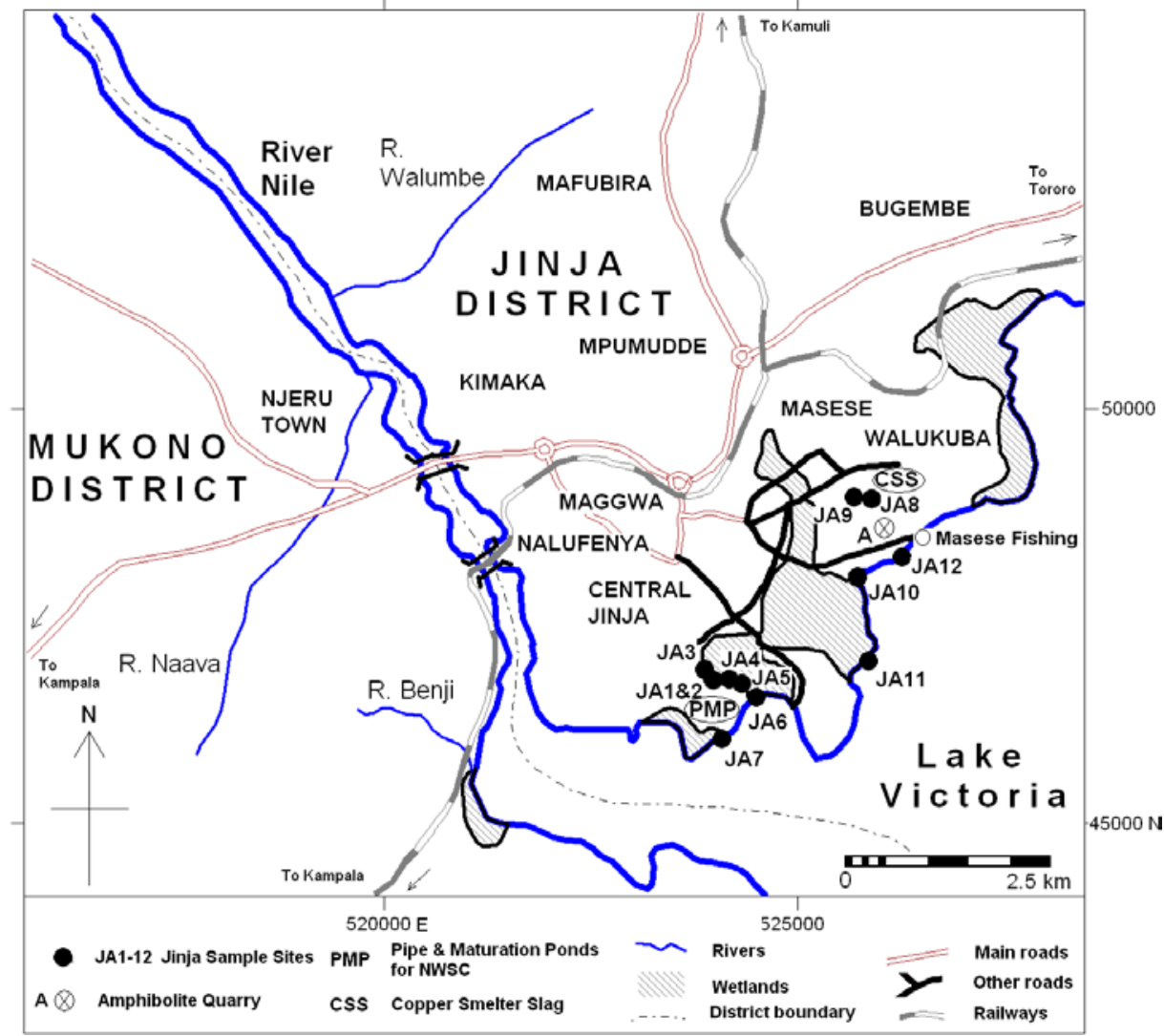

Figure 3:. Map showing sample locations in Jinja 
The copper slag trail from Walukuba hill was systematically sampled up to the wetland and within Lake Victoria after the wetland.

\section{Berkeley Bay (Busia)}

The sampling was first done near the source of the rivers Nasigombe (after Lunyo town) and Nalwire before Hukeno (Makina) trading centre (Fig.4). All the rivers (Nasigombe, Nalwire and Sio) were then sampled at points before the wetland and within Lake Victoria after the water has gone through the wetland. Two samples were collected from river Tira to test the influence of artisan gold mining.

\section{MATERIALS AND METHODS}

\section{Treatment of Samples}

Water

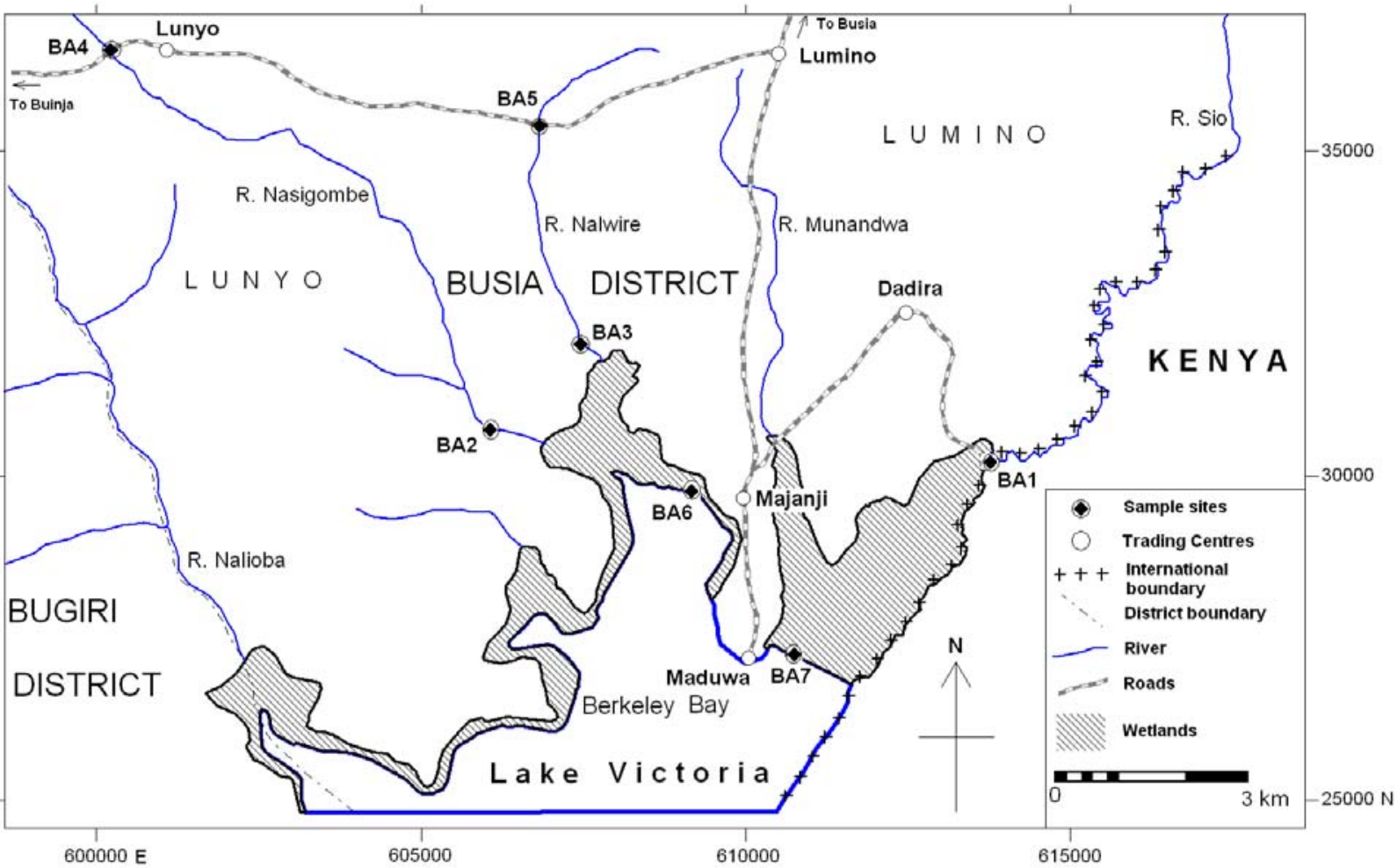

Figure 4: Map showing sample locations in Busia

\section{MATERIALSAND METHODS}

\section{Treatment of Samples}

Water

The water was filtered using cellulose nitrate filter papers $(0.45 \mu \mathrm{m}$ pore size $)$ and 3 drops of concentrated nitric acid were added for preservation. The bottles were put back in the deep freezer at $4^{\circ} \mathrm{C}$ until they were dispatched to the University of Dar Es Salaam, Tanzania for heavy metal analysis.

\section{Soils and Sediments}

The samples were spread on aluminium foil and dried overnight in an oven set at $105^{\circ} \mathrm{C}$. After cooling, they were pulverised in a ceramic agate mortar and sieved in nylon sieves to 80 mesh and packed in heavy duty polyethylene bags.

Fish

The fish was preserved whole in the cooler and then later The water was filtered using cellulose nitrate filter papers 
$(0.45 \mu \mathrm{m}$ pore size $)$ and 3 drops of concentrated nitric acid nitric acid were added for preservation. The bottles were put back in the deep freezer at $4^{\circ} \mathrm{C}$ until they were dispatched to the University of Dar Es Salaam, Tanzania for heavy metal analysis.

\section{Soils and Sediments}

The samples were spread on aluminium foil and dried overnight in an oven set at $105^{\circ} \mathrm{C}$. After cooling, they were pulverised in a ceramic agate mortar and sieved in nylon sieves to 80 mesh and packed in heavy duty polyethylene bags.

\section{Fish}

The fish was preserved whole in the cooler and then later in the deep freezer. The fish was dissected and the dorsal muscle freeze dried in the freeze drying facility at the Department of Biochemistry.

\section{Analysis of Samples}

All the analysis of heavy metals was done at the Southern and Eastern Mineral Centre (SEAMIC) Tananzania using a Flame Atomic Absorption Spectrophotometer (AAS).

\section{Soil and Sediments}

These were analysed for heavy metals. $0.5 \mathrm{~g}$ of each sample was digested with $2 \mathrm{ml}$ aqua regia $\left(\mathrm{HCl} / \mathrm{HNO}_{3} 3: 1\right)$ in a test tube placed in a water bath. The water bath was thermostatically controlled at 95 ÚC. After cooling the samples was diluted to $20 \mathrm{ml}$ and vigorously mixed by a vortex shaker, and then left to settle. The clear solution analysed for heavy metals $\mathrm{Cu}, \mathrm{Pb}, \mathrm{Zn}, \mathrm{Cd}, \mathrm{Co}, \mathrm{Ni}, \mathrm{Cr}$ and Mn.

\section{Water}

Each sample was directly aspirated into the AAS without any prior treatment.

\section{Fish}

This was also analysed using AAS.

\section{Mercury}

For total mercury (THg) analysis, 0.5 to $1 \mathrm{~g}$ of sediment or fish muscle tissue were placed in a thick-walled $50 \mathrm{ml}$ volumetric flask and digested with $2 \mathrm{ml}$ of $\mathrm{HNO}_{3}-\mathrm{HClO}_{4}$ mixture (1:1) plus $5 \mathrm{ml}$ of $\mathrm{H}_{2} \mathrm{SO}_{4}$ for 20 minutes at $205^{\circ} \mathrm{C}$ on a hot plate. After cooling, the digested sample was made up to $50 \mathrm{ml}$ by adding mercury-free water to the digestion vessel. The vessel was then capped and shaken vigorously to homogenize the sample solution. Analysis of $\mathrm{THg}$ in the solution was done by cold vapour atomic absorption (CVAA) using a semi-automated mercury analyser.

\section{RESULTS}

\section{Water}

\section{Physico-chemical Parameters}

\section{Nakivubo Channel}

Results are shown in Table 1. High $\mathrm{pH}$ values, up to 9.5, are observed in the effluents from Uganda Breweries, which enter directly into the lake. At other places, the $\mathrm{pH}$ was within accepted levels.

Table1. Physico - chemical properties of Nakivubo Channel waters

\begin{tabular}{|c|c|c|c|c|}
\hline Sample & $\mathbf{p H}$ & $\begin{array}{c}\text { EC } \\
(\boldsymbol{\mu S} / \mathbf{c m})\end{array}$ & $\begin{array}{c}\text { Turb. } \\
(\mathbf{N T U})\end{array}$ & $\begin{array}{c}\text { Oxygen } \\
\mathbf{m b a r}\end{array}$ \\
\hline NC1 & 5.6 & 226 & 17.19 & 104 \\
\hline NC1 & 7.5 & 444 & 182.7 & 37 \\
\hline NC2 & 7.5 & 444 & 182.7 & 29 \\
\hline NC3 & 6.9 & 293 & 17.58 & 68 \\
\hline NC 4 & 7.3 & 449 & 60.93 & 14 \\
\hline NC 5 & 7.3 & 487 & 25.88 & 23 \\
\hline NC 6 & 6.8 & 516 & 898.4 & 2 \\
\hline NC 7 & 6.8 & 492 & 177.5 & 2 \\
\hline NC 8 & 7.1 & 510 & 20.1 & 69 \\
\hline NC 9 & 7.2 & 813 & 121.3 & 4 \\
\hline NC 10 & 7.4 & 45000 & 219 & 79 \\
\hline NC 11 & 6.2 & 624 & 15.96 & 36 \\
\hline NC 12 & 7.4 & 461 & 22.81 & 36 \\
\hline NC 15 & 7.3 & 465 & 22.03 & 17 \\
\hline NC 16 & 9.5 & 667 & 43.78 & 110 \\
\hline NC 17 & 7.4 & 291 & 9.74 & 130 \\
\hline NC 18 & 7.6 & 350 & 17.47 & 60 \\
\hline NC 19 & 7.4 & 174 & 17.37 & 93 \\
\hline NC 20 & 7.4 & 351 & 15.09 & 106 \\
\hline NC 22 & 6.9 & 319 & 11.02 & 33 \\
\hline NC 23 & 7.9 & 129 & 11.03 & 161 \\
\hline NC 24 & 6.9 & 195.8 & 17.22 & 9 \\
\hline NC 25 & 6.4 & 80.5 & 14.74 & 153 \\
\hline NEMA (MPL) ${ }^{\text {a }}$ & $6.0-8.0$ & - & 300 & \\
\hline WHO Guidelines b & $6.5-8.5$ & 400 & & \\
\hline & & & & \\
\hline
\end{tabular}

${ }^{a}$ NEMA Maximum Permissible Limits for Discharge of Effluent or Waste Water

${ }^{\mathrm{b}}$ World Health organisation guidelines for drinking water quality (1984)

Effluents from a skin and hides factory (Easthides) have very high electrical conductivity - EC - $(45000 \mu \mathrm{S} / \mathrm{cm})$ indicating high dissolved solids which could include chromium. Below the factory, local people cultivate yams, sweet potatoes and sugar canes. WHO and EU guidelines give $400 \mu \mathrm{S} / \mathrm{cm}$ as the guide level for potable water. Of the 25 sites sampled, only seven have EC falling below EC guidelines. 
Impact of Industrial Activities on Heavy Metal Loading and their Physico-Chemical Effects on Wetlands of Lake Victoria Basin (Uganda)

Turbidity in most places is below NEMA standards effluent discharge of 300 NTU but is higher where the water effluent from industry joins the channel e.g. NC 6 from after Mukwano Industries and NC 10 near Easthides skin tanning plant. Oxygen is also low where water contains sewage indicating possibly high oxygen demand by the microorganisms in the sewage and organic material.

\section{Kinawataka Stream and Ntinda Industrial Area}

EC is highest in runoff from industries along Jinja Road (Table 2) as shown by samples KW 4 and KW 7 . Other high values are observed some distance from the industrial area suggesting influence of geology and possibly vegetation.

Table 2. Physicochemical properties of waters from Kinawattka stream and Ntinda Industrial Area

\begin{tabular}{|c|c|c|c|c|}
\hline Sample & $\mathbf{p H}$ & $\begin{array}{c}\mathbf{E C} \\
(\boldsymbol{\mu S / c m})\end{array}$ & $\begin{array}{c}\text { Turb. } \\
(\mathbf{N T U})\end{array}$ & $\begin{array}{c}\text { Oxygen } \\
\text { mbar }\end{array}$ \\
\hline KW 1 & 6 & 474 & 156 & 37 \\
\hline KW 2 & 6.8 & 190.8 & 72.17 & 111 \\
\hline KW 3 & 7.4 & 187.1 & 30.89 & 116 \\
\hline KW 4 & 6.1 & 720 & 79.2 & 67 \\
\hline KW 5 & 6.6 & 220 & 83.24 & 65 \\
\hline KW 6 & 7.1 & 282 & 120.3 & 58 \\
\hline KW 7 & 7.3 & 762 & 142.2 & 23 \\
\hline KW 8 & 7.6 & 449 & 177.1 & 46 \\
\hline KW 9 & 7 & 386 & 57.84 & 0 \\
\hline KW 10 & 7.2 & 386 & 52.02 & 67 \\
\hline KW 11 & 6.9 & 189.9 & 43.62 & 60 \\
\hline NEMA (MPL) & $6.0-8.0$ & & 300 & \\
\hline WHO Guidelines & $6.5-8.5$ & 400 & & \\
\hline
\end{tabular}

Turbidity is highest within Ntinda industrial area and streams receiving effluents from industries on Jinja road (KW 1, KW 7 and KW 8). Oxygen is lowest within the wetland and this could be due to vegetation matter.

\section{Jinja}

Water and effluent $\mathrm{pH}$ values in Jinja were generally high (7.5-9.0) (Table 3) compared to those recorded in Nakivubo Channel and Kinawataka areas in Kampala.
Table3. Physico - chemical properties of Jinja waters

\begin{tabular}{|c|c|c|c|c|}
\hline Sample & $\mathbf{p H}$ & $\begin{array}{c}\text { EC } \\
(\boldsymbol{\mu S / c m})\end{array}$ & $\begin{array}{c}\text { Turb. } \\
(\mathbf{N T U )})\end{array}$ & $\begin{array}{c}\text { Oxygen } \\
\mathbf{m b a r}\end{array}$ \\
\hline JA 1 & 8.4 & 884 & 39.8 & 149 \\
\hline JA 2 & 7.8 & 867 & 239.3 & 12 \\
\hline JA 3 & 8.3 & 891 & 45.61 & 157 \\
\hline JA 4 & 7.9 & 914 & 66.28 & 13 \\
\hline JA 5 & 7.7 & 820 & 190.3 & 1 \\
\hline JA 6 & 8.8 & 102.4 & 20.28 & 144 \\
\hline JA 7 & 9 & 101.3 & 23.75 & 160 \\
\hline JA 10 & 9.1 & 2530 & 297 & 83 \\
\hline JA 1 1 & 9.4 & 103.3 & 30.93 & 177 \\
\hline JA 12 & 9.4 & 103.1 & 49.15 & 182 \\
\hline NEMA (MPL) & $6.0-8.0$ & & 300 & \\
\hline WHO Guidelines & $6.5-8.5$ & 400 & & \\
\hline
\end{tabular}

High EC values ( 860 to $890 \mu \mathrm{S} / \mathrm{cm}$ ) are recorded in the NWSC wastewater and runoff from the former copper smelting plant $(2530 \mu \mathrm{S} / \mathrm{cm})$, indicating high dissolved solids. Metals contained in the slag could be entering the lake.

\section{Busia}

Busia wetlands exhibit normal levels of physico-chemical parameters and thus are pristine or little disturbed (Table 4). One point (BA 5), however, had a high EC value (1820 $\mu \mathrm{S} / \mathrm{cm})$, which is probably due to the influence of grazing.

Table 4. Physico - chemical properties of Busia waters

\begin{tabular}{|c|c|c|c|c|}
\hline Sample & pH & $\begin{array}{c}\text { EC } \\
(\mu \mathrm{S} / \mathrm{cm}) \\
\end{array}$ & $\begin{array}{l}\text { Turb. } \\
\text { (NTU) }\end{array}$ & $\begin{array}{c}\text { Oxygen } \\
\text { mbar }\end{array}$ \\
\hline BA1 & 7.03 & 168.5 & 28.22 & 159 \\
\hline BA2 & 8.84 & 700 & 718.9 & 196 \\
\hline BA5 & 7.44 & 1822 & 150 & 75 \\
\hline BA6 & 8.41 & 112.9 & 149 & 149 \\
\hline BA7 & 8.06 & 109 & 40.19 & 165 \\
\hline BA8 & 6.92 & 220 & 29.76 & 106 \\
\hline BA9 & 6.31 & 219 & 25.65 & 78 \\
\hline NEMA (MPL) & $6.0-8.0$ & & 300 & \\
\hline WHO Guidelines & $6.5-8.5$ & 400 & & \\
\hline
\end{tabular}

Heavy Metals

Water

The metal contents of water from the sampled areas are given in Table 5 and are compared to the NEMA maximum permissible contents in industrial effluent. In Nakivubo 
Table 5. Heavy metal contents (in mg/l) water

\begin{tabular}{|c|c|c|c|c|c|c|c|c|}
\hline \multicolumn{9}{|c|}{ Nakivubo Channel } \\
\hline Sample & $\mathbf{C u}$ & $\mathbf{P b}$ & $\mathbf{Z n}$ & Cd & $\mathrm{Cr}$ & $\mathbf{N i}$ & Co & Mn \\
\hline NC1-A & 0.02 & 0.06 & 0.01 & \begin{tabular}{|l|}
0.001 \\
\end{tabular} & $<0.01$ & 0.01 & 0.08 & 1.2 \\
\hline $\mathrm{NC} 2$ & 0.01 & 0.01 & 0.01 & 0.012 & $<0.01$ & 0.01 & 0.08 & 0.25 \\
\hline NC5 & 0.01 & 0.01 & 0.01 & 0.001 & $<0.01$ & 0.03 & 0.04 & 0.03 \\
\hline NC5-B & 0.01 & 0.06 & 0.01 & 0.001 & $<0.01$ & 0.03 & 0.06 & 0.46 \\
\hline NC7 & 0.01 & 0.01 & 0.01 & 0.001 & $<0.01$ & 0.01 & 0.07 & 0.81 \\
\hline NC9 & 0.01 & 0.22 & 0.02 & 0.001 & $<0.01$ & 0.05 & 0.11 & 0.45 \\
\hline $\mathrm{NC10}$ & 0.02 & 0.26 & 0.06 & 0.014 & $<0.01$ & 0.13 & 0.16 & 0.44 \\
\hline NC11 & 0.01 & 0.11 & \begin{tabular}{l|l|}
0.12 \\
\end{tabular} & 0.001 & $<0.01$ & 0.03 & 0.09 & 0.82 \\
\hline NC12 & 0.01 & 0.06 & 0.01 & 0.001 & $<0.01$ & 0.01 & 0.07 & 0.79 \\
\hline NC15 & 0.01 & 0.24 & 0.01 & 0.001 & $<0.01$ & 0.05 & 0.11 & 0.59 \\
\hline NC16 & 0.01 & 0.11 & 0.04 & 0.009 & $<0.01$ & 0.05 & 0.06 & 0.07 \\
\hline NC20 & 0.01 & 0.01 & 0.01 & 0.01 & $<0.01$ & 0.01 & 0.06 & 0.05 \\
\hline NC22 & 0.01 & 0.01 & 0.01 & 0.01 & $<0.01$ & 0.03 & 0.08 & 0.58 \\
\hline $\mathrm{NC} 23$ & 0.01 & 0.01 & 0.01 & 0.014 & $<0.01$ & 0.01 & 0.06 & 0.01 \\
\hline \multicolumn{9}{|c|}{ Kinawattaka Stream } \\
\hline KW2b & 0.06 & 1.44 & 0.01 & 0.001 & 0.02 & 0.01 & 0.06 & 1.17 \\
\hline KW3 & 0.01 & 0.01 & 0.01 & 0.001 & 0.01 & 0.01 & 0.01 & 0.85 \\
\hline KW5 & 0.01 & 0.01 & 0.01 & 0.018 & 0.01 & 0.01 & 0.01 & 0.4 \\
\hline KW6 & 0.01 & 0.28 & 0.01 & 0.016 & 0.01 & 0.01 & 0.01 & 1.04 \\
\hline KW7 & 0.01 & 0.01 & 0.01 & 0.012 & 0.01 & 0.01 & 0.01 & 0.93 \\
\hline KW8 & 0.01 & 0.13 & 0.01 & 0.014 & 0.01 & 0.01 & 0.01 & 0.91 \\
\hline KW9 & 0.01 & 0.01 & 0.01 & 0.009 & 0.01 & 0.01 & 0.01 & 0.42 \\
\hline KW10 & 0.01 & 0.09 & 0.01 & 0.013 & 0.01 & 0.01 & 0.01 & 0.7 \\
\hline \multicolumn{9}{|l|}{ Jinja } \\
\hline JA1 & 0.01 & 0.01 & 0.01 & 0.019 & 0.01 & 0.01 & 0.05 & 0.04 \\
\hline JA2 & 0.01 & 0.01 & 0.01 & 0.014 & 0.01 & 0.01 & 0.01 & 0.23 \\
\hline \begin{tabular}{|l|} 
JA44 \\
\end{tabular} & 0.02 & 0.01 & 0.01 & 0.019 & 0.01 & 0.04 & 0.01 & 0.26 \\
\hline JA6 & 0.01 & 0.01 & 0.01 & 0.015 & 0.01 & 0.01 & 0.01 & 0.01 \\
\hline JA7 & 0.01 & 0.01 & 0.01 & 0.018 & 0.01 & 0.01 & 0.01 & 0.03 \\
\hline JA10 & 0.02 & 0.26 & 0.01 & 0.014 & 0.02 & 0.07 & 0.16 & 0.35 \\
\hline \begin{tabular}{|l|} 
JA11 \\
\end{tabular} & 0.01 & 0.1 & 0.01 & 0.001 & 0.01 & 0.01 & 0.05 & 0.01 \\
\hline \multicolumn{9}{|l|}{ Busia } \\
\hline BA1 & $<0.01$ & 0.03 & $<0.01$ & $<0.001$ & $<0.01$ & $<0.01$ & 0.01 & 0.03 \\
\hline$\overline{B A 6}$ & $<0.01$ & 0.01 & $<0.01$ & $<0.001$ & $<0.01$ & $<0.01$ & 0.01 & 0.01 \\
\hline BA7 & $<0.01$ & 0.09 & $<0.01$ & $<0.001$ & $<0.01$ & $<0.01$ & 0.05 & 0.02 \\
\hline NEMA MPL & 1 & 0.1 & 5 & 0.1 & 1 & 1 & 1 & 1 \\
\hline WHO & 0.1 & 0.05 & & 0.005 & & 0.05 & & \\
\hline
\end{tabular}

Channel, most of the samples from all the areas are below the NEMA maximum permissible levels for effluent for all the analysed heavy metals apart from lead. Three samples from Nakivubo Channel (NC9, 10 and NC11) have unacceptable values for $\mathrm{Pb}(0.06$ to $0.24 \mathrm{mg} / \mathrm{l})$. NC9 is after the effluent of National Water and Sewerage Corporation (NWSC), NC 10 from a hides and skins processing plant and $\mathrm{NC} 11$ is effluent below several industries including Uganda Batteries Ltd (Fig 2).

Three samples (KW2b, KW6 and KW8) from Kinawattaka stream have more than acceptable values for $\mathrm{Pb}$ in the Ntinda-Nakawa industrial area. The highest value of 1.4 $\mathrm{mg} / \mathrm{l}$ (KW2b) is from the blue effluent of the Kampala Pharmaceutical Industry and is over ten times the NEMA guidelines for effluent discharge. KW 6 is effluent from Ntinda Industrial area and KW 8 is below Oxygas (oxygen and acetylene plant).

Two samples from Jinja (JA10 and JA11 downstream of a former copper smelting plant) have higher than acceptable values for $\mathrm{Pb}(0.1-0.26 \mathrm{ppm})$.

All water samples from Busia have metal contents below NEMA acceptable limits and WHO guidelines values.

\section{Soil and sediments}

The distribution of heavy metals in various materials sampled from the wetlands is shown in Table 6 and compared to average values of an uncontaminated shale (Foerstner \& Wittmann, 1979).

At the source of the Nakivubo Channel (Bat Valley area) there are elevated levels of $\mathrm{Pb}$ (35.9 ppm) and $\mathrm{Cr}$ (119.6 in the sediments (sample NC 1). The same applies to a sample after Mukwano Industries (about $30 \mathrm{~m}$ downstream) with $50.7 \mathrm{ppm} \mathrm{Pb}$ and $156.9 \mathrm{ppm} \mathrm{Cr}$ (sample NC 5). Samples from below the National Water and Sewerage Corporation (NC9), Easthide hides processing plant (NC 10) and effluent from Uganda Baati (various steel products), Uganda Batteries and Casements Ltd. (assorted metal frames) (NC 11) are also enriched in $\mathrm{Pb}$ (74.4-157.2 ppm). The sediments after the paint-packing factories (NC 10), upstream of Mukwano Industries (NC 2) effluent from Uganda Batteries and other industries (NC 11), contained elevated values $\mathrm{Zn}(158-1641 \mathrm{ppm})$ and $\mathrm{Cr}(79.1 \mathrm{ppm})$.

Along Kinawattaka stream, there are high values of $\mathrm{Pb}$ in sediments from upstream of the Industrial Area below a petrol station supplying leaded fuel (KW 3), downstream of Britania food and Hwang Sung fish processing plants and SWT tanners - dealers in hides and skins - (KW 5) and at Oxygas (oxygen and acetylene gas plant) (KW 8) ranging between 30.8 and $106.7 \mathrm{ppm}$. Samples KW 3 and KW 5 also have high concentrations of $\mathrm{Cr}$ (116.2 and 153.2 ppm respectively. The sediments from around Oxygas have enriched concentration of $\mathrm{Cd}(0.56 \mathrm{ppm})$ and $\mathrm{Zn}$ (589 $\mathrm{ppm}$ ). Sediments taken from where runoff from a vehicle washing bay (KW 9) joins the stream shows elevated contents of $\mathrm{Zn}(175.9 \mathrm{ppm})$. 
Impact of Industrial Activities on Heavy Metal Loading and their Physico-Chemical Effects on Wetlands of Lake Victoria Basin (Uganda)

Table 6. Heavy metals (in ppm) in sediments

\begin{tabular}{|c|c|c|c|c|c|c|c|c|}
\hline \multicolumn{9}{|c|}{ Nakivubo Channel } \\
\hline Sample & $\mathbf{C u}$ & $\mathbf{P b}$ & $\mathbf{Z n}$ & Cd & $\mathbf{C r}$ & $\mathbf{N i}$ & Co & Mn \\
\hline $\mathrm{NC} 1$ & 18.6 & 35.9 & 47.8 & $<0.001$ & 119.6 & 15.7 & 7 & 226 \\
\hline $\mathrm{NC2}$ & 18.9 & 23 & 158.4 & $<0.001$ & 63.3 & 8.2 & 4 & 141.5 \\
\hline NC5 & 24.8 & 50.7 & 73.9 & $<0.001$ & 156.9 & 14 & 8 & 594 \\
\hline NC7 & 16 & 21.3 & 101 & $<0.001$ & 79.1 & 10.2 & 3.8 & 101.8 \\
\hline NC9 & 11.5 & 28.2 & 66.3 & $<0.001$ & 58.6 & 10 & 3.4 & 104.4 \\
\hline NC10 & 24.9 & 157.2 & 1641 & $<0.001$ & 93.1 & 22.3 & 9.8 & 250.3 \\
\hline$\overline{\mathrm{C} 11}$ & 24.3 & 74.4 & 229 & $<0.001$ & 270 & 19.8 & 9.4 & 245.2 \\
\hline NC12 & 9.5 & 20.5 & 68.2 & $<0.001$ & 41.8 & 10 & 5.4 & 123.8 \\
\hline NC15 & 12.2 & 21.7 & 18.3 & $<0.001$ & 57.6 & 10.3 & 6 & 210.3 \\
\hline \multicolumn{9}{|c|}{ Kinawattaka stream } \\
\hline KW3 & 20.2 & 30.8 & 41.4 & 0.001 & 116.2 & 19.7 & 9.8 & 438.6 \\
\hline KW5 & 24.9 & 31.4 & 57.3 & 0.194 & 153.2 & 19.8 & 9.7 & 230.4 \\
\hline KW6 & 14.9 & 16.2 & 38.9 & 0.077 & 83.3 & 11.7 & 4.7 & 155.6 \\
\hline KW7 & 7.6 & 17.6 & 9.8 & 0.001 & 14 & 9.1 & 2.8 & 141.8 \\
\hline KW8 & 24.7 & 106.7 & 589 & 0.564 & 54.9 & 24.6 & 9.4 & 478.5 \\
\hline KW9 & 17.8 & 26.7 & 175.9 & 0.171 & 39.9 & 17.7 & 5.6 & 166.7 \\
\hline KW10 & 8.9 & 20.5 & $\overline{71.7}$ & 0.086 & 22 & 11.7 & 10.3 & 625.5 \\
\hline \multicolumn{9}{|l|}{\begin{tabular}{|l|} 
Jinja \\
\end{tabular}} \\
\hline JA2 & 4.2 & 0.2 & 30 & 0.001 & 2.3 & 0.7 & 0.4 & 36.1 \\
\hline JA7 & 75.6 & 15.9 & 78.8 & 0.403 & 271 & 80.3 & 46.5 & 1358 \\
\hline JA10 & 142.3 & 14.1 & 72.1 & 0.34 & 102.9 & 84.7 & 26.4 & 512.9 \\
\hline \multicolumn{9}{|l|}{ Busia } \\
\hline BA1 & 17.3 & 2.9 & 7.5 & $<0.001$ & 19.7 & 12.1 & 7.6 & 583.9 \\
\hline BA6 & 11.7 & 2.5 & 9 & $<0.001$ & 75.1 & 16.5 & 7.7 & 259.7 \\
\hline BA7 & 1.7 & 0.9 & 2.9 & $<0.001$ & 12.9 & 2.4 & 1.7 & 85.1 \\
\hline hale standard* & 45 & 20 & 95 & 0.3 & 90 & 68 & 19 & 850 \\
\hline
\end{tabular}

* After Foerstner \& Wittmann (1979)

In Jinja, a sediment sample (JA7) picked on the shores of Lake Victoria below the leather tannery has high concentrations of $\mathrm{Cr}$ (271 ppm), $\mathrm{Cu}$ (75.6 ppm), Ni (80.3 ppm) and cobalt (46.5 ppm). A sample (JA10) on the trail for the copper slag from the smelter that was picked from the fringes of the Kirinya wetland at Masese has elevated values of $\mathrm{Cu}$ (142.3 ppm), $\mathrm{Cr}$ (102.9 ppm), $\mathrm{Ni}$ (84.7 ppm) and $\mathrm{Co}(26.4 \mathrm{ppm})$.

The Berkeley Bay in Busia wetland is pristine. All the sediments sampled from rivers draining the wetland plus the Lake Victoria sediment samples have low concentrations of $\mathrm{Cu}, \mathrm{Pb}, \mathrm{Zn}, \mathrm{Cd}, \mathrm{Cr}$, Ni and $\mathrm{Co}$.

\section{Mercury}

Because of the toxic nature of mercury, selected samples were analysed for mercury. These were samples that had shown high metal contents in Kampala and Jinja, and from Busia. The results are given in Table 7.
Table 7. Mercury contents in sediments

\begin{tabular}{|l|r|}
\hline Sample & THg ng/g dw \\
\hline Nakivubo Channel & \\
\hline NC1 & 65.6 \\
\hline NC2 & 37.8 \\
\hline NC5 & 108.1 \\
\hline NC10 & 95.1 \\
\hline Jinja & \\
\hline JA 7 & 64.8 \\
\hline JA 10 & 19.4 \\
\hline Busia & \\
\hline BA 1 & 41.4 \\
\hline BA 6 & 28.0 \\
\hline BA 7 & 33.4 \\
\hline
\end{tabular}

Normal soils have $\mathrm{Hg}$ concentrations around $100 \mathrm{ppb} \mathrm{dw}$ and only the sample NC5 (108.1 ng/g dw) which was collected after Mukwano Industry exceeds the value.

\section{Fish}

Fish samples could only be located from a few places along Lake Victoria shores close to Nakivubo channel. The results are given in the Table 8 below.

Table 8. Mercury content in fish

\begin{tabular}{|l|r|}
\hline Sample & THg (ng/g) dw \\
\hline NC15(1) & 28.3 \\
\hline NC15(1) & 32.7 \\
\hline NC15(3) & 38.9 \\
\hline NC15(4) & 28.5 \\
\hline NC17 & 20.3 \\
\hline
\end{tabular}

The European Commission recommends a limit of 0.5-1 ppm $(500-1000 \mathrm{ng} / \mathrm{g}) \mathrm{Hg}$ in fish. The Hg concentrations determined in the fish samples are below the limit value.

\section{DISCUSSION}

The European Commission recommends a limit of 0.5-1 ppm $(500-1000 \mathrm{ng} / \mathrm{g}) \mathrm{Hg}$ in fish. The Hg concentrations determined in the fish samples are below the limit value.

The buffering capacity of any wetland (Okurut et al. 2000) can indirectly be monitored by the measurement of its physical parameters $(\mathrm{pH}, \mathrm{EC}, \mathrm{Eh}, \mathrm{NTU}$, oxygen content and temperature). This can be augmented the determination of the heavy metal uptake by the various species in the wetland (e.g. fish, plants). Different 
organisms may have tolerable levels for the different heavy metal concentrations. Deficiencies can cause some deformities and some high concentrations are stressful or toxic and in extreme circumstances they become fatal.

\section{Water}

In this investigation, some hotspot areas with anomalous values of physico-chemical parameters have been identified. High $\mathrm{pH}$ values occur in the effluent from Uganda Breweries Ltd. The basic water may have an effect on organisms sensitive to high $\mathrm{pH}$.

High EC values exceeding EC guidelines for drinking water are recorded in several locations including effluent from downtown areas, downstream of Mukwano Industry, within the Industrial Area both along Nakivubo Channel and Kinawattaka stream. The highest value of EC was measured in effluent from Easthide skin processing plant indicating high Total Dissolved Solids (TDS) emanating from the chemicals used in the tanning process. In Jinja, high EC values occur in water around the NWSC water treatment plant and downstream of the former copper smelting plant. Most industries in Jinja release their effluent in the NWSC sewer network and this could explain the presence of relatively high TDS in the treated sewage. High TDS downstream of the former copper smelter would originate from metals released from the slag stockpile that was left behind after operations ceased. The high TDS at one site in Busia where there is no industrial activity may be due its being a watering point for cattle. High TDS may be a result of decomposition of faeces releasing phosphates and nitrates.

Most of the heavy metals are below maximum permissible limits for both NEMA and WHO. In the Nakivubo Channel samples with $\mathrm{Pb}$ values exceeding the WHO limits include samples from National Housing Corporation housing estate, downstream of Uganda Batteries Ltd. and NWSC effluent. This could be ascribed to lead from $\mathrm{PbO}$ paints, battery manufacture and dilapidated lead sewage pipes. Along Kinawataka stream, samples with high $\mathrm{Pb}$ values are from the Kampala Pharmaceutical Industry (1.4 mg/1 being 14 times the NEMA acceptable value for effluent) and the Ntinda-Nakawa industrial area. The $\mathrm{Pb}$ could be originating from the leaded fuel in the industries and the chemicals used in manufacture of drugs that may contain $\mathrm{Pb}$-organo compounds. Disposal sites for old batteries left at petrol stations are not known and these could also contribute to the $\mathrm{Pb}$. In Jinja, high $\mathrm{Pb}$ contents are recorded in samples from downstream of the former copper smelter. $\mathrm{The} \mathrm{Pb}$ could be originating from slag that was left behind.
Some could be coming from the fuel used to operate the crushers and other equipment at the nearby amphibolite quarry in Masese

This could be ascribed to the leaded fuel used in the industries spilling over into the effluents.

\section{Heavy Metals in Sediments}

\section{Lead}

The $\mathrm{Pb}$ levels in some sediments around the Uganda Batteries and metal frames factories are relatively high and they need to be thoroughly investigated. Although $\mathrm{Pb}$ is expected to have low phytotoxicity (Chino, 1981) because of its strong affinity to organic matter, when environmental conditions e.g. change in $\mathrm{pH}$, it may become mobile. The area downstream is heavily cultivated. This may go into the food chain. Two samples of fish are between 1.2 to 5 times higher than acceptable values of 1 ppm $\mathrm{Pb}$.

A remedy must be sought for the $\mathrm{Pb}$ levels in the effluents of the industries where the metal is high in effluents. The use of leaded fuel is expected to stop at the end of 2006.

\section{Copper}

The average $\mathrm{Cu}$ content in soils/sediments is considered to be about $30 \mathrm{ppm}$. The $\mathrm{Cu}$ analyses in the present study are within acceptable range, except for the samples from the copper slag trail in Jinja, which show elevated Cu levels. Although copper toxicity in humans is rare, aquatic organisms are potentially at risk from $\mathrm{Cu}$ exposures (Adriano, 2001). Given that areas showing high $\mathrm{Cu}$ concentrations are on the fringes of the lake, mitigation measures are required to reduce $\mathrm{Cu}$ inflow into the lake. The fish samples analysed, however, have $\mathrm{Cu}$ concentrations below maximum permissible values.

\section{Zinc}

The average concentration of $\mathrm{Zn}$ in soils/sediments is 90 ppm. The sediments collected from around Uganda Baati (galvanised iron sheets factory), effluent of Ntinda Nakawa Industrial Area have high concentrations of Zn. The factories upstream dealing in galvanised scrap may be releasing $\mathrm{Zn}$ into the effluent.

$\mathrm{Zn}$ is an essential macronutrient for plants but is phytotoxic when in excess. Phytotoxicity may cause decreased crop yield and quality and likelihood of $\mathrm{Zn}$ transfer into the food chain (Adriano, 2001). 
Impact of Industrial Activities on Heavy Metal Loading and their Physico-Chemical Effects on Wetlands of Lake Victoria Basin (Uganda)

\section{Cadmium}

The average $\mathrm{Cd}$ content in soils is $0.35 \mathrm{ppm}$. The sediments sampled during this investigation have lower values except samples associated with the former $\mathrm{Cu}$ smelter and industrial operations involving $\mathrm{Zn}$ scrap. A sample taken slightly away from the mouth of Nakivubo Channel into Lake Victoria has 1.9 ppm for Cd. This was mostly peat got from rotten Cyperus papyrus. The organic matter there was capable of complexing with Cd especially from the sewage sludge.

Cadmium is a non-essential element. It is both bioavailable and toxic. It interferes with metabolic processes in plants and can bioaccumulate in aquatic organisms and enter the food chain (Adriano, 2001). Though the concentrations obtained are not extremely high, effluents from locations where elevated values are obtained should be treated before discharging into the environment.

Chromium

The average $\mathrm{Cr}$ concentration in soils is reported to be 40 $50 \mathrm{ppm}$. Some samples in this study had high $\mathrm{Cr}$ concentrations, possibly due to $\mathrm{Cr}$ released in the effluent during industrial operations, pharmaceutical industry and from the former $\mathrm{Cu}$ smelter.

In most soils, $\mathrm{Cr}$ phytotoxicity is expected from $\mathrm{Cr}$ (VI) as it may interfere with nutrient metabolism of plants causing stunted growth, poorly developed root systems and discoloured leaves (McGrath, 1991). When it enters the food chain, $\mathrm{Cr}(\mathrm{VI})$ is toxic to humans. The effluents with high $\mathrm{Cr}$ contents should be treated before discharge.

\section{Nickel}

The average $\mathrm{Ni}$ concentration in soils/sediments is reported as $20 \mathrm{ppm}$. High Ni concentrations are associated with the $\mathrm{Cu}$ smelting. The $\mathrm{Cu}$ slag is still rolling downhill up to the wetland and therefore impacting on it.

Although Ni is relatively less toxic to invertebrates, it can be toxic to aquatic organisms such as reduction in skeletal calcification and diffusion capacity of gills (Moore, 1991). The runoff from the slag may therefore affect fish in the lake.

\section{Cobalt}

The average abundance of Co in soils/sediments is around 8 ppm (Adriano, 2001). Apart from samples taken around the former $\mathrm{Cu}$ smelter, the majority of the analysed sediments have concentrations within this acceptable range. High Co concentrations are attributed to the breakdown of the sulphides associated with the Kilembe ore that was smelted at Jinja.

Cobalt is relatively non-toxic animals and man and deficiency of Co is of far greater concern than potential toxic levels in plants (Smith, 1990).

\section{Manganese}

The average abundance of $\mathrm{Mn}$ in the shale standard is $850 \mathrm{ppm}$. The Mn concentration for the sediments that were analysed, except a sample from around a tannery in Jinja, is below this value indicating that the $\mathrm{Mn}$ in sediments could be due to lithological variations. The high Mn value seems to be related to tanning activities.

\section{Mercury}

Normal soils have $\mathrm{Hg}$ concentrations around $100 \mathrm{ppb} \mathrm{DW}$. The sediment samples which were analysed fall within the above value apart from a sample picked after Mukwano Industry. It is possible there is a bit of $\mathrm{Hg}$ additive in the soap manufactured in the industry. As pointed out by Campbell et al. (2003), use of beauty creams containing high inorganic $\mathrm{Hg}$ concentrations, may pose a threat to $\mathrm{THg}$ exposure.

The Hg concentrations determined in the fish samples are below the limit value. There is therefore no threat of $\mathrm{Hg}$ contamination. Average values have been found to be between 24.2 to $35.4 \mathrm{THg}$ (ng/g WW) in the Protopterus aethiopicus (Lung fish) indicating that $\mathrm{Hg}$ concentrations in fish were below WHO concentrations and international marketing limits (The European Commission recommends a limit of 0.5-1 ppm $\mathrm{Hg}$ in fish). Campbell et al. (2004) observed that the low $\mathrm{THg}$ concentrations in fish were attributed to the storage capacity, high oxygen concentrations and high organic matter content. They, however, caution that this should not be taken for granted as the storage capacity and the methylation rates present in the wetlands of are unknown and the gradual accumulation of $\mathrm{THg}$ contamination from other sources (e.g. atmospheric $\mathrm{THg}$ ) may result in unexpected $\mathrm{THg}$ increases in the biota.

\section{CONCLUSIONS}

\section{Physico-chemical Parameters}

Along the Nakivubo Channel, most physico-chemical parameters are within acceptable limits. Notable is high $\mathrm{pH}$ in effluent from Uganda Breweries Ltd. probably due materials used in beer brewing and high EC related to 
high metal loads from Hides and Skins plant which indicates high ionic concentrations while only effluents after Mukwano Industries and Easthide had high turbidity. The high turbidity is ascribed to sewage and effluent from skin tanning.

Along Kinawattaka stream industries along Jinja road contribute to metal loading into the water resulting into high EC values. In the wetlands, low values of oxygen are likely to be due decomposition of organic matter. In Jinja the high EC values in NWSC wastewater and runoff from the former copper smelting plant indicate that metals from contained in the slag enter the lake. NWSC treatment plant does not remove inorganic pollutants which result in high EC. Although the Busia wetlands exhibit normal levels of physico-chemical parameters and thus are pristine or little disturbed, one site had a high EC value which is probably due to the influence of grazing.

\section{Heavy Metals}

\section{Water}

Along Nakivubo Channel, the metals of concern are $\mathrm{Pb}$ and Cr especially below the NWSC sewage treatment plant and Easthide hides and skin factory which correlates with the high EC contents. Apparently the $\mathrm{Cr}$-containing chemicals used for skin tanning ends up in the environment. Along Kinawattaka stream, high $\mathrm{Pb}$ values seem to be associated with pharmaceuticals and the acetylene gas plant. In jinja, high $\mathrm{Cu}$ and $\mathrm{Pb}$ are linked to the former $\mathrm{Cu}$ smelter.

\section{Soils/Sediments}

Just as in water, along Nakivubo Channel high $\mathrm{Pb}$ and $\mathrm{Cr}$ contents occur near the skin and hides factory but also near petrol stations and factories of steel products. Zinc and $\mathrm{Cr}$ is also relatively high in the industrial area where there are paint industries. This is likely to be due to pigments used in the paint industry. Along Kinawataka stream, $\mathrm{Zn}$ is high near a washing bay while soil near the acetylene plant has high Cd contents. In Jinja, the tannery contributes to $\mathrm{Cr}$ pollution while the former $\mathrm{Cu}$ smelter is responsible for $\mathrm{Cu}$ loading into the soils. Industries whose effluent is heavily loaded with heavy metals should first treat their effluent before it is discharged into the environment.

\section{Mercury}

Mercury concentrations both in soils and fish are tolerable with only one sample having slightly higher than normal contents. The fish is at the moment safe although fish is known to bioaccumulate mercury.

\section{ACKNOWLEDGEMENT}

The team would like to thank Prof. Z. Ogutu thanked for his continuous encouragement and follow up of the research activities at various stages of the project. We are very grateful to the project sponsors Sida-SAREC and the Inter-University Council of East Africa (IUCEA) for the financial assistance which made the research possible. The VicRes Secretariat facilitated all necessary logistics in connection with the project activities and finances. The University provided administrative support to the project and the Department of Geology allowed us to use laboratory facilities for the research work.

\section{REFERENCES}

Adriano, D.C. (2001): Trace elements in terrestrial environments: Biochemistry, bioavailabilty and risks of metals. Springer Verlag. 867 pp.

Chino. M, 1981: In: Kitagishi, K. \& Yamane, I. Eds. Heavy metal pollution in soils of Japan,. Japan Sci. Coc. Proc.

Foestner, U. \& Wittmann, G.T.W. (1979); Metal pollution in the aquatic environment. Springer, Heidelberg, 486pp.

Haskoning - CMS, 2001a, Lake Victoria Environmental Management Project, cost benefit analysis of wetlands resources Uganda, Part III: Wetland characteristics and development scenarios, Final Report; Delt Hydraulics.

Haskoning-CMS, 2001b, Lake Victoria Environmental Management Project, cost benefit analysis of wetlands resources Uganda, Part IV: Economic analysis, Final Report; Delt Hydraulics.

Kansiime, F., Kateyo, E. and Okot-Okumu, J., 1995, Effects of pollution of inner Murchison Bay, Lake Victoria, Uganda, on the distribution and abundance of plankton.

Kansiime, F., Nalubega, M., Van Bruggen, J.J.A and Denny, P., 2003, The effect of wastewater discharge on biomass production and nutrient content of cyperus papyrus and miscanthidium violaceum in the Nakivubo wetland, Kampala, Uganda; water science and Technology, Vol. 48, IWA publishing, 233-240 
Linda M Campbel, L.M.l, Dixon, D.G. \& Hecky, R.E. (2003): A review of mercury in Lake Victoria, East Africa: Implications for human and ecosystem health. Journal of Toxicology and Environmental Health, Part B, 6:325-356,

Linda M Campbel, L.M.1, Balirwa, J.S., Dixon, D.G. \& Hecky, R.E. (2004): Biomagnification of mercury in fish from Thruston Bay, Napoleon Gulf, Lake Victoria (East Africa). African Journal of Aquatic Science, 29(1): 91-96

Mafabi, P., Kakuru, W., Arinaitwe, J. and Kizito, Y., 1998, Wetlands resources subsector component stocktaking report on Uganda's biodiversity strategy and action plan, (BSAP).

McGrath, S.P. \& Smith, S. (1990): Chromium and Nickel, In: AllowAY, B.J. (ed.). Heavy metals, p. 125 - 150, Blackie, Glasgow.

Moore, J.W. (1991): Inorganic Contaminants in surface water. Sprenger Verlag, New York

Mott MacDonald, 2001, Lake Victoria Environmental Management Project, Management of industrial and municipal effluents and urban runoff in the Lake
Victoria basin, final report, Vol. 1, main report, NWSC, Ministry of Water, Lands and Environment.

Namakambo, N., 2000, Kampala wetlands; National Wetlands Programme.

Swallow, B.M., Walsch, M, Mugo, F., Ong, C., Shepherd, K., Place, F., Awiti, A. Mwangi, H., Ombalo, D., Ochieng, O., Mwarasomba, L., Muhia, J., Nyantika, D., Cohen, M., Mungai, D., Wangila, J., Mbole, F., Kiara, J. and Eriksson, A., 2001, Improved land management of the Lake Victoria basin: Annual technical report.

Okurut, T., Kansiime, F., Busulwa, H., Mwebembezi, L., Malinga, A. and Barugahare, V., 2000, Lake Victoria Environmental Management Project, Wetlands Component, Buffering capacity of wetlands subcomponent: Buffering capacity of Kinawataka and Kisoma wetlands report; Ministry of Water, Lands and Environment.

Smith, K.A. (1990): Manganese and Cobalt, p.197-221 In Alloway A J.(ed). Heavy metals in soils, Blackie, Glasgow. 